\title{
Article \\ Qualifying the TIG orbital welding technology of titanium pipes with a perforated bottom
}

\author{
Jacek Górka1,* (D), Mateusz Przybyła ${ }^{2}$, Andrzej Chudzio², Dariusz Ładak², Marcin Szmul² \\ 1 Silesian University of Technology, Poland \\ 2 Famet S.A., Kędzierzyn Koźle; office@famet.com.pl \\ * Correspondence: jacek.gorka@polsl.pl
}

Received: 02.02.2020; Accepted: 26.03.2020

\begin{abstract}
The article presents the method of qualifying orbital welding technology using the TIG (142) method of the perforated bottom heat exchanger made of steel A516M (Grade 485) explosively clad with titanium B265 (Grade 1) with titanium pipes B338 (Grade 2) with a diameter of $34.93 \mathrm{~mm}$ and thickness 0.7 $\mathrm{mm}$. Based on preliminary tests, welding technologies have been developed that meet the acceptance criteria for acceptance requirements. Qualification of the developed technology and welding parameters that were used during welding was carried out in accordance with PN-EN ISO 15614 Specification and qualification of metal welding technology, welding technology testing, Part 8: Welding of tubes with perforated bottom. This standard specifies the requirements for the qualification of automatic arc welding technology, metal pipe joints with perforated bottom by means of technology testing. As part of the tests, the test joints were subjected to: visual tests, penetration tests, radiographic tests and macroscopic tests.
\end{abstract}

Keywords: orbital welding; TIG; perforated bottom; titanium; clad steel

\section{Introduction}

Nowadays, industry faces many challenges in the field of welding technologies. It is connected with the growing range of new materials available, as well as with the requirements for joining currently known welding methods $[1 \div 6]$. The development of technology to date allows the design of welded structures from many materials such as steels, aluminum alloys, nickel alloys, magnesium alloys and titanium alloys. Each of these materials requires a different approach when designing technology for combining them, and this is due to the diversity of physical properties. Titanium alloys due to their high relative strength and very good corrosion resistance are an ideal choice when designing heavily loaded structures or ultimately working in highly aggressive corrosive environments. The use of titanium mainly concerns the energy, chemical, food as well as aviation industries. In the energy industry, it is particularly important to ensure uninterrupted and correct operation of apparatus and devices for long periods of time (often reaching 30-40 years). Hence, the use of titanium in heat exchangers, in which the cooling medium is water rich in chlorides and sulfides, which in combination with high temperature makes it a threat from the corrosion point of view for exchanger elements [7:13]. Shell-and-tube heat exchangers currently account for more than half when it comes to the quantity of this type of equipment used in industrial installations. Due to the medium that is responsible for receiving heat, there are some restrictions when it comes to the use of materials used for pipes that are inside the exchanger [14:22]. This is related to corrosion resistance, because e.g. in the case of sea water flow or water rich in sulfides and chlorides inside the pipes, it is necessary to use titanium alloys. In each of the varieties of shell and tube heat exchangers, the pipes must be connected to the perforated bottom (the pipes are not connected to the partitions, they are freely mounted). For this purpose, among others, welding technologies are used. Among the technologies of connecting pipes with tube sheets, such methods are used: welding, rolling, gluing or also explosive welding [23:26]. PN-EN ISO 15614 Specification and qualification of metal welding technology, welding technology testing, Part 8: Welding of tubes with perforated bottom, specifies the requirements for the qualification of automatic arc welding technology, metal joints of tubes with perforated bottom by means of technology testing, this applies to both load-bearing joints as well as joints welded only for sealing. According to the guidelines of this standard, welding instructions should contain such data as:

- welding method/methods (if more than one method is used to obtain a full joint),

- technical conditions for the delivery of the test plate (plate thickness),

- technical conditions for the delivery of the pipes (outer diameter and wall thickness), 
- pitch type and the distance between pipes,

- joint geometry, actual hole size,

- welding position,

- cleaning and degreasing (cleaning and degreasing methods),

- type and name of welding consumables (if used),

- electrode diameter,

- minimum heating temperature (it is also possible to indicate the interpass temperature when welding in more than one pass),

- welding speed (in the case of automated, mechanized and robotic welding).

\section{Own research}

The purpose of the work was to conduct tests of the TIG orbital welding process (142) of the perforated bottom of a heat exchanger made of steel plated with B265 Gr. 1 titanium with B338 Gr. 2 titanium pipes (Fig. 1). As part of the tests, a test plate was made, allowing welding technology qualification.
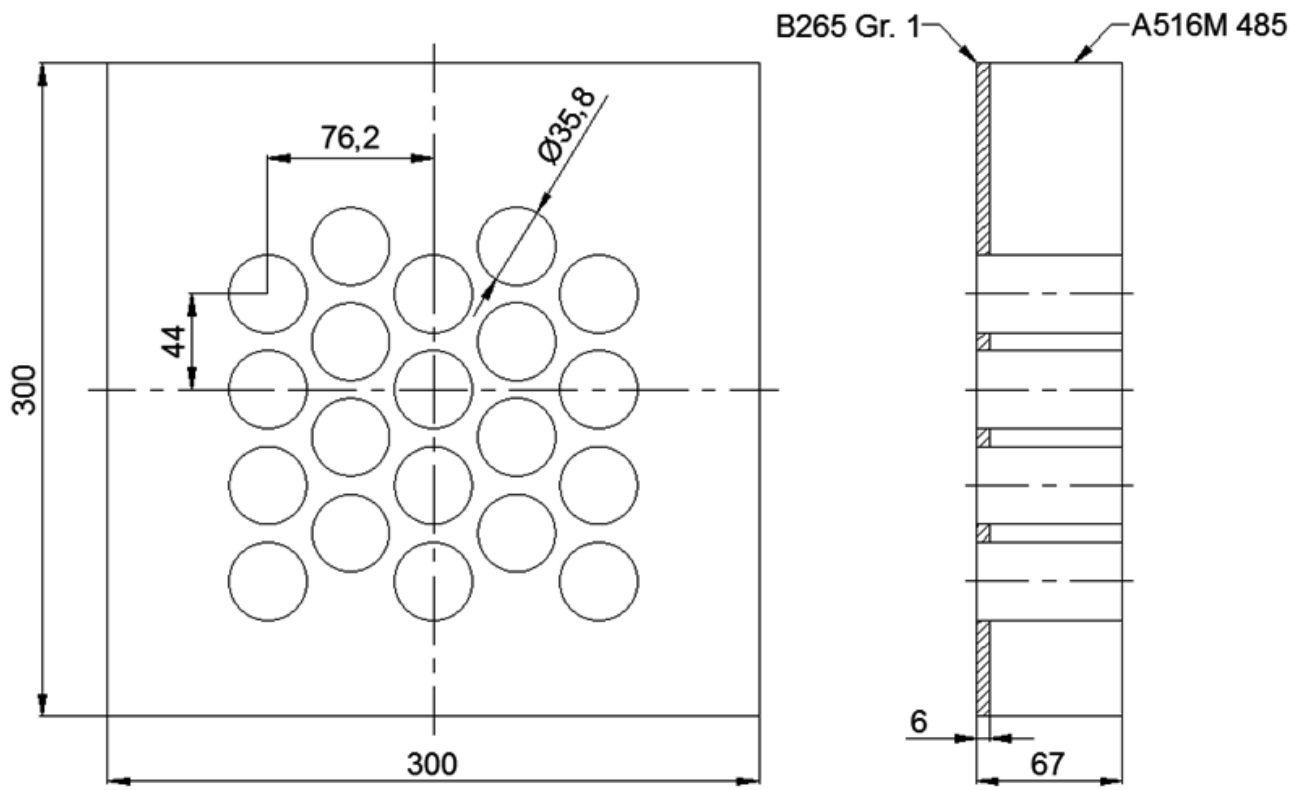

Fig. 1. Diagram of the tube sheet test plate

\section{Making of the test joint}

Test plate made of non-alloy steel A516M Grade 485 plated with B265 Grade 1 titanium using the explosive method. The $300 \times 300 \mathrm{~mm}$ plate consisted of $60 \mathrm{~mm}$ thick unalloyed steel layers and $5 \mathrm{~mm}$ titanium plating and had 20 holes drilled in a triangular pattern, in which pipes with a diameter of $\varnothing 34.93 \mathrm{~mm}$ made of B338 Grade 2 titanium with a thickness of 0,7 were welded. The chemical composition of the tested materials is presented in table I.

Table I. Chemical composition of tested materials

\begin{tabular}{ccccccccccc}
\hline & \multicolumn{10}{c}{ Chemical composition [\%] } \\
& C & Si & Mn & Al & Cr & S & Fe & H & N & O \\
\hline A516M Gr. 485 & $0.1 \div 0.2$ & 0.6 & 1.05 & 0.02 & 0.3 & 0.03 & - & - & - & - \\
Titanium Grade 1 & $\leq 0.1$ & - & - & - & - & - & $\leq 0.2$ & $\leq 0.015$ & $\leq 0.03$ & $\leq 0.18$ \\
Titanium Grade 2 & $\leq 0.1$ & - & - & - & - & - & $\leq 0.3$ & $\leq 0.015$ & $\leq 0.03$ & $\leq 0.25$ \\
\hline
\end{tabular}

The welding process was carried out on an orbital welding device using the TIG method. The welding current was $55 \mathrm{~A}$, the electrode travel speed was $20 \mathrm{~cm} / \mathrm{min}$, the arc voltage was about $9.0 \mathrm{~V}$, the DC current was set with negative polarity, and the heat input of the welding process was $0.41 \mathrm{~kJ} / \mathrm{cm}$. A tungsten electrode with a diameter of $1.6 \mathrm{~mm}$ and a sharpening angle of $30^{\circ}$ were used. The shielding gas intensity (argon with a purity of $99.998 \%$ ) was set at $30 \mathrm{l} / \mathrm{min}$. Figure 2 shows a test plate with the numbering of joints after cutting with a ball cutter. 


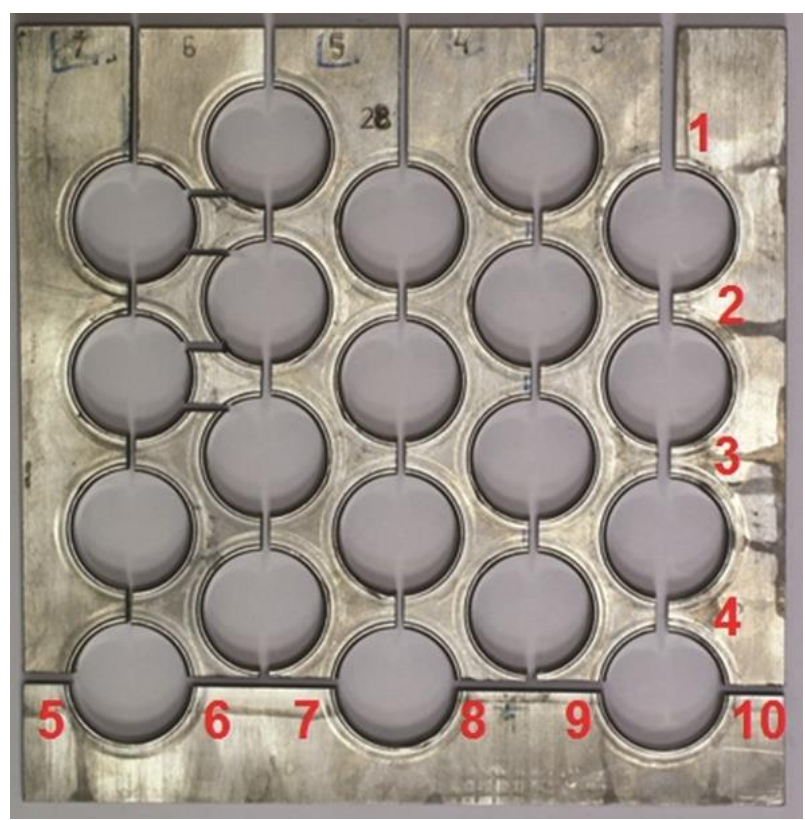

Fig. 2. Test plate with numbering of joints after cutting with a ball cutter

\section{The process of making a test plate for qualifying the welding technology}

The making of the test plate included the following stages:

- degreasing pipes and holes of the perforated bottom;

- measuring holes in the test plate before welding;

- rolling of titanium pipes to obtain mechanical restraint inside the holes of test plates. The degree of rolling obtained as a result of the process was between 10 and $20 \%$;

- measuring internal diameter of titanium pipes;

- planning the tip of titanium pipes. After planning and brushing, the tube may protrude from the sieve up to $0.3 \mathrm{~mm}$ (Fig. 3);

- carrying out the welding process in accordance with the prepared WPSs. The PN-EN ISO 15614-8 standard also very precisely defines how the ends of the pipes are to be located. For the test plate, the pipe pitch was triangular. Also remember to prepare at least 10 pipes in the test plate and weld to qualify the technology in accordance with the guidelines;

- visual inspection. According to the guidelines, $100 \%$ of joints should be subjected to visual tests;

- penetration tests. According to the guidelines, $100 \%$ of joints should be subjected to penetration tests;

- conducting radiographic tests;

- macroscopic examination. To carry them out, cut the test plate with a saw or, optionally, by machining, in such a way that the cutting line runs through the two starting points for the welding of root beads.

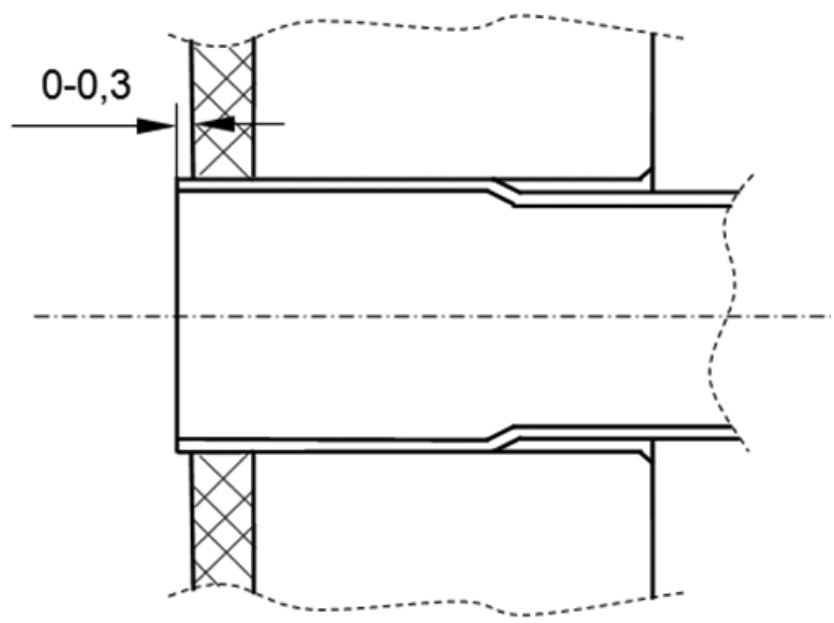

Fig. 3. Diagram of a correctly prepared pipe for further processes 


\section{Analysis of test results}

The test joint made with the assumed technology was subjected to visual tests in accordance with PNEN ISO 17637: 2011, adopting acceptance criteria according to PN-EN ISO 15614-8: 2005. Visual tests did not show any inconsistencies that would not fall within the approved acceptance criteria. The joints were characterized by horizontal quality B. Also, penetration tests carried out according to PN-EN ISO 3452-1: 2013 and the acceptance criteria according to PN-EN ISO 23277: 2010 did not show welding defects (Fig. 4).

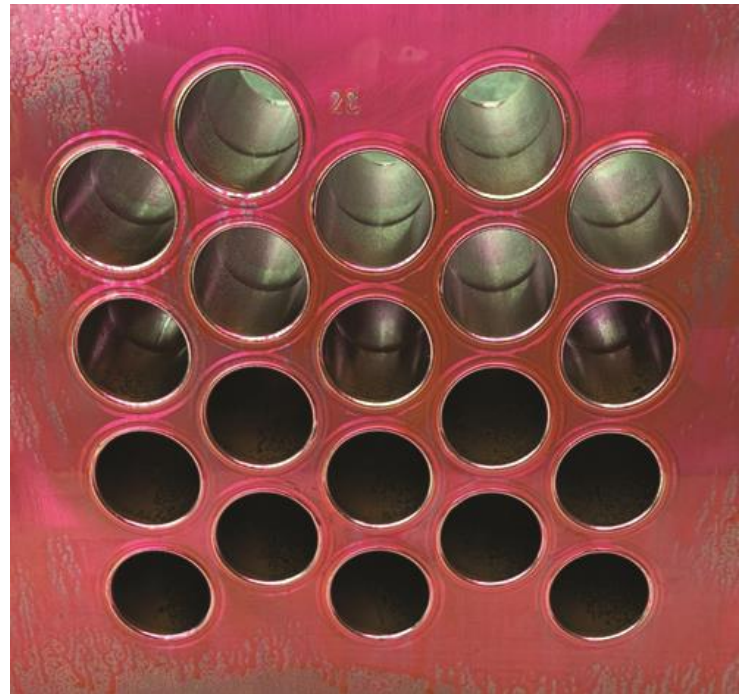

(a)

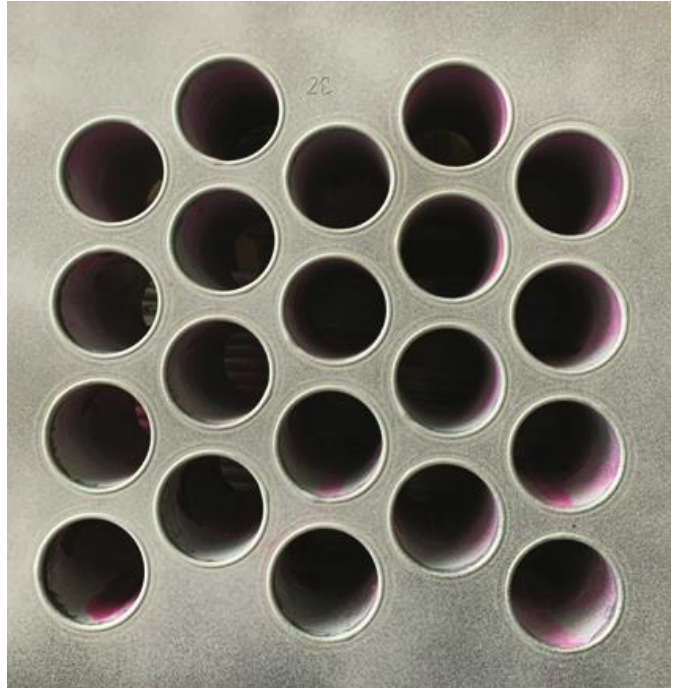

(b)

Fig. 4. View of a test plate subjected to a penetration test: a) with a penetrant applied, b) with a developer

Radiographic tests were carried out based on PN-EN ISO 17636-1: 2013, adopting acceptance criteria according to PN-EN ISO 6520-1: 2009. The test conditions were: lamp voltage $150 \mathrm{kV}$, lamp current $3 \mathrm{~mA}$, exposure time 70 seconds, source-film distance FFD $700 \mathrm{~mm}$, radiation type $-X$, the length of the rated segment for each film is $110 \mathrm{~mm}$. Interpretation of the results obtained during the RT examination did not show any inconsistencies that would prevent acceptance according to the approved acceptance criteria (Fig. 5).

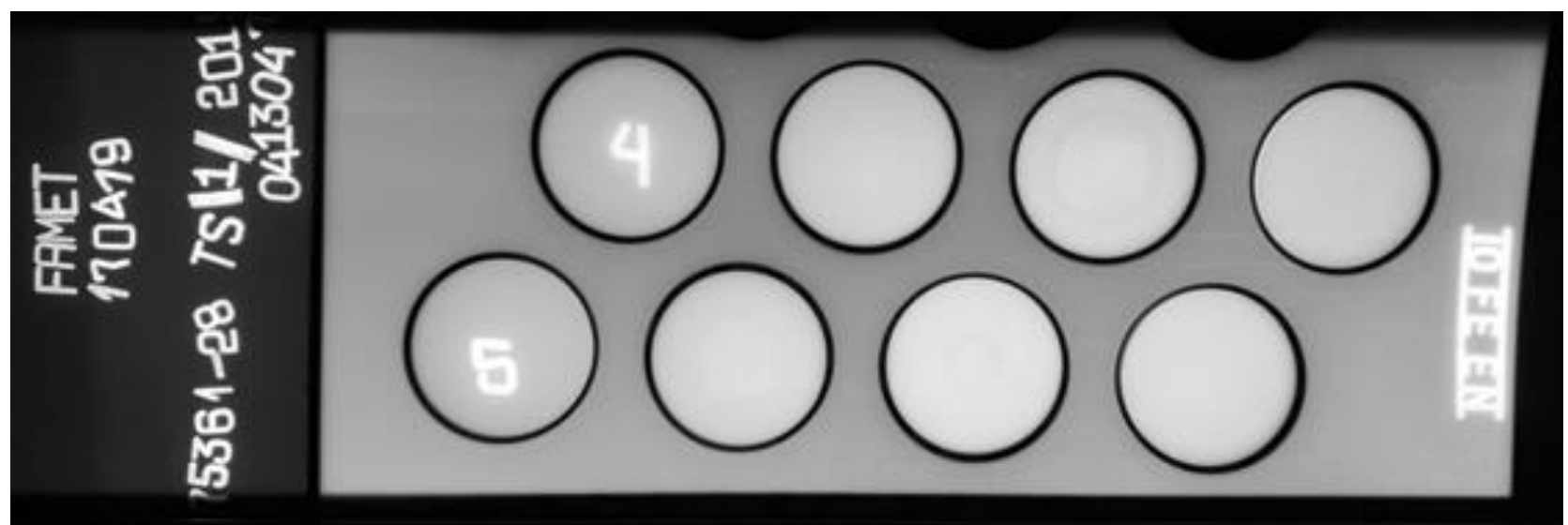

Fig. 5. Image obtained as a result of the X-ray examinations of the fourth and fifth row of joints

PN-EN ISO 15614-8 standard in point 7.2.5 - Macroscopic tests, specifies the "a" weld dimension. This dimension is equal to the radius of the largest circle, which is completely inscribed into the weld and whose center is at the lowest point of the ridge. The dimension size must meet the condition $a \geq 0.9 t$, where $t$ is the wall thickness of the pipe (Fig. 6).

When taking photos of the specimens using a light microscope, the size $a$ was measured. The values obtained did not exceed $0.63 \mathrm{~mm}$ (for a pipe with a wall thickness of $t=0.7$, the dimension $0.9 \mathrm{t}$ is $0.63 \mathrm{~mm}$ ). Therefore, macroscopic examinations showed that the weld meets the requirements of PN-EN ISO 15614-8: 2005 from the point of view of geometry (Fig. 7). 


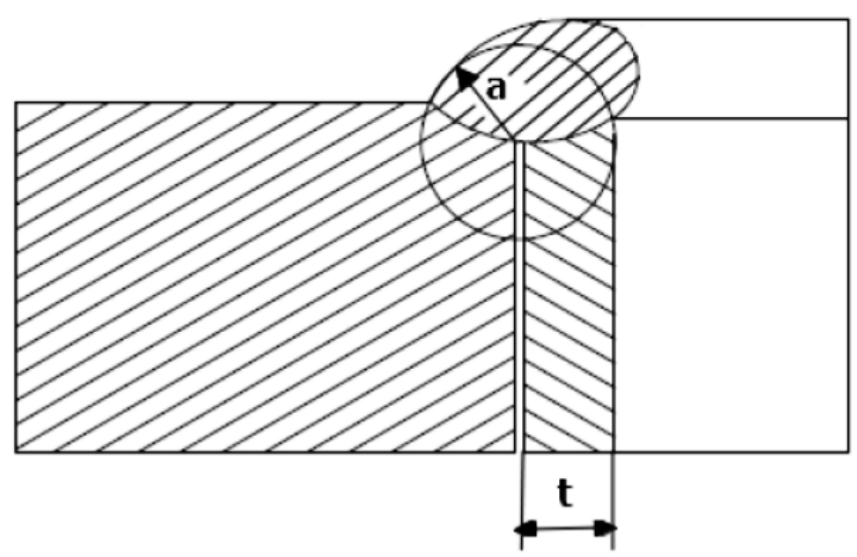

Fig. 6. Diagram showing how to enter a circle at the lowest point of a ridge with radius " $a "$

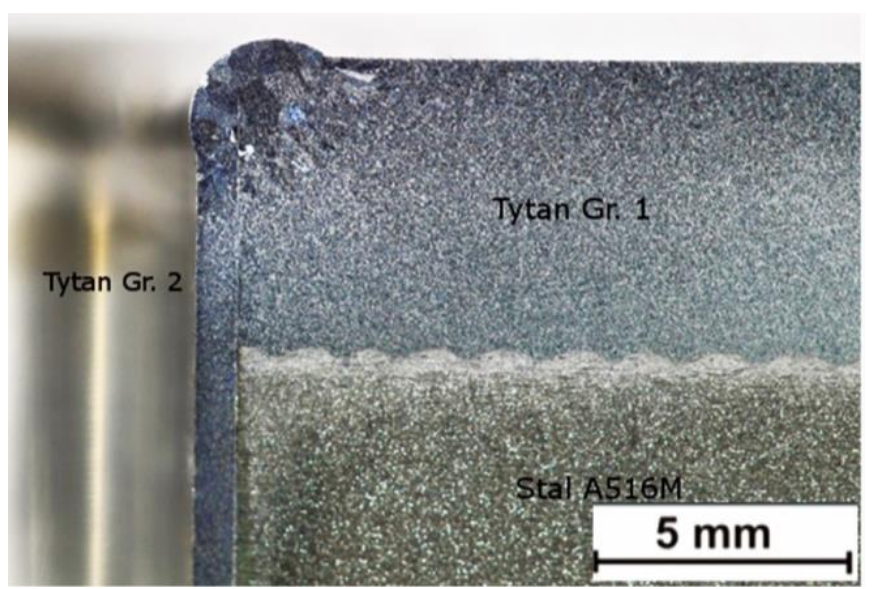

Fig. 7. Macrostructure of joint No. 7 (designation according to figure 2)

\section{Summary}

Earlier studies [27] conducted by the Authors showed that in order to ensure the quality of the connection of titanium pipes with the perforated bottom, it is necessary to constantly control the welding process. During the industrial process, there may be defects associated with inadequate shielding of the protective gas, incorrect positioning of the tungsten electrode (on too large or small track circumference), too high speed of electrode movement resulting from an incorrectly set welding program, as well as too high current during welding.

Based on the performed TIG (142) orbital welding tests of the perforated bottom of the heat exchanger made of B265 Gr.1 titanium plated steel with B338 Gr.2 titanium pipes, the following conclusions can be drawn:

- the test plate made in accordance with technological assumptions met all the requirements necessary to qualify the technology of welding pipes with perforated bottom. There were no problems with compliance with the guidelines of PN-EN ISO 15614-8: 2005 both on the side of non-destructive tests and macrographic tests;

- a necessary condition for the correct execution of welded joints of titanium alloys is a tight and intense shield of inert gas (e.g. argon);

- preparation of the joint before welding by thoroughly cleaning the area of the target weld, significantly reduces the formation of incompatibilities;

- designing welding technology for 142 titanium pipes with a tube sheet requires many analyzes and tests to determine the right welding parameters during the implementation of the technology in production conditions.

Author Contributions: conceptualization J. G., M. P.; methodology J. G., A. C., D. Ł.; formal analysis J. G., M. P.; investigation M. S., D. Ł., A. C.; writing-original draft preparation M. P.; writing-review and editing, J G.

Funding: This research received no external funding.

Conflicts of Interest: The authors declare no conflict of interest. 


\section{References}

[1] Vandewynckéle A., Vaamonde E., Fontán M., Herwig P., Mascioletti A., Laser welding head tailored to tube-sheet joint requirements for heat exchangers manufacturing. Physics Procedia, 2013, Vol. 41, 144-52.

https://doi.org/10.1016/j.phpro.2013.03.063

[2] Henon B.K., Brond A., Mosciaro H., Orbital welding best competition. Welding Design E Fabrication, 2002, Vol. 75, 28-54.

[3] Rogalski G., Fydrych D., Łabanowski J., Underwater Wet Repair Welding of API 5L X65M Pipeline Steel. Polish Maritime Research, 2017, Vol. 24(s1), 188-94. https://doi.org/10.1515/pomr-2017-0038

[4] Giętka T., Ciechacki K., Kik T., Numerical Simulation of Duplex Steel Multipass Welding. Archives of Metallurgy and Materials, 2016, Vol. 61(4), 1975-84. https://doi.org/10.1515/amm-2016-0319

[5] Gorka J., Smyczek B., A technology for the welding of tubes to perforated, clad tube plates. Welding International, 1995, Vol. 9(10), 776-80. https://doi.org/10.1080/09507119509548894

[6] Lin J., Ma N., Liu X., Lei Y., Modification of residual stress distribution in welded joint of titanium alloy with multi electron beam heating. Journal of Materials Processing Technology, 2020, Vol. 278, 116504. https://doi.org/10.1016/j.jmatprotec.2019.116504

[7] Król S., Bański R., Szulc Z., Gałka A., Practical aspects of structural test of titanium-steel bonds made by explosive cladding and exposed to thermal process loads. Advances in Materials Science, 2007, Vol. 7(4(14)), 50-6.

[8] Chaze A.M., Coddet C., Influence of alloying elements on the dissolution of oxygen in the metallic phase during the oxidation of titanium alloys. Journal of Materials Science, 1987, Vol. 22(4), 1206-14. https://doi.org/10.1007/BF01233110

[9] Onyszkiewicz E., Czynniki technologiczne wpływające na odporność na pękanie stopu tytanu alfa+beta. Solidifikation of Metals and Alloys, 1997, Vol. 33, 187-92.

[10] Talkington J., Harwig D., Castner H., Mitchell G., Development of Titanium Weld Color Inspection Tools. Welding Journal, 2000, Vol. 79(3), 35-8.

[11] Margolin H., Nielsen J.P., Titanum Metallurgy - Modern materials advances in development and applications. Vol. 2, New York - London: Academic Press. 1960. 225-325

[12] Campet R., Roy P.T., Cuenot B., Riber É., Jouhaud J.C., Design optimization of an heat exchanger using Gaussian process. International Journal of Heat and Mass Transfer, 2020, Vol. 150, 119264.

https://doi.org/10.1016/j.ijheatmasstransfer.2019.119264

[13] Höft S., Grahn S., Bialuch I., Augustin W., Scholl S., Low-Fouling Heat Exchanger for Biofuel Usage in Combined Heat and Power Units. Heat Transfer Engineering, 2020, Vol. 41, 311-23. https://doi.org/10.1080/01457632.2018.1540452

[14] Irving B., McCue D., Gas Tungsten Arc Welding: It's Built to Handle Titanium. Welding Journal, 1992, Vol. 11, 317.

[15] Lathabai S., Jarvis B.L., Barton K.J., Comparison of keyhole and conventional gas tungsten arc welds in commercially pure titanium. Materials Science and Engineering A, 2001, Vol. 299(1-2), 81-93. https://doi.org/10.1016/S0921-5093(00)01408-8

[16] Newkirk J.B., Geisler A.H., Crystallography of the alfa and beta transformation in Ti. Acta Metallurgica, 1953, Vol. $1,370-4$.

[17] Ellis M.B.D., Gittos M.F., Tungsten inert gas welding of titanium and its alloys. Welding E Metal Fabrication, 1995, Vol. 1, 9-14.

[18] Khorshidi J., Heidari S., Design and Construction of a Spiral Heat Exchanger. Advances in Chemical Engineering and Science, 2016, Vol. 06(02), 201-8. https://doi.org/10.4236/aces.2016.62021

[19] Tomków J., Fydrych D., Rogalski G., Łabanowski J., Effect of the welding environment and storage time of electrodes on the diffusible hydrogen content in deposited metal. Revista de Metalurgia, 2019, Vol. 55(1), e140. https://doi.org/10.3989/revmetalm.140

[20] Kumar P., Pai A., An overview of welding aspects and challenges during manufacture of Intermediate Heat Exchangers for 500MWe Prototype Fast Breeder Reactor. Procedia Engineering, 2014, Vol. 86, 173-83. https://doi.org/10.1016/j.proeng.2014.11.026

[21] Leonov V.P., Mikhailov V.I., Sakharov I.Y., Kuznetsov S. V., Welding of high-strength titanium alloys of large thicknesses for use in marine environments. Inorganic Materials: Applied Research, 2016, Vol. 7(6), 877-83. https://doi.org/10.1134/S2075113316060083

[22] Farrahi G.H., Chamani M., Kiyoumarsioskouei A., Mahmoudi A.H., The effect of plugging of tubes on failure of shell and tube heat exchanger. Engineering Failure Analysis, 2019, Vol. 104, 545-59.

https://doi.org/10.1016/j.engfailanal.2019.06.034 
[23] Lothongkum G., Chaumbai P., Bhandhubanyong P., TIG pulse welding of 304L austenitic stainless steel in flat, vertical and overhead positions. Journal of Materials Processing Technology, 1999, Vol. 89-90, 410-4. https://doi.org/10.1016/S0924-0136(99)00046-1

[24] Lisiecki A., Effect of heat input during disk laser bead-on-plate welding of thermomechanically rolled steel on penetration characteristics and porosity formation in the weld metal. Archives of Metallurgy and Materials, 2016, Vol. 61(1), 93-101. https://doi.org/10.1515/amm-2016-0019

[25] Benway A., Advancements in automatic orbital welding expand its use, provide welders with more option. Industrial Maintenance \& Plant Operation, 2000, Vol. 61, 22.

[26] Otegui J.L., Booman J.N., Massone J., Experimental assessment of thermal grain boundary embrittlement after tubeplate failure in a petrochemical heat exchanger. Engineering Failure Analysis, 2017, Vol. 79, 140-53. https://doi.org/10.1016/j.engfailanal.2017.04.022

[27] Górka J., Przybyła M., Szmul M., Chudzio A., Ładak D., Orbital TIG Welding of Titanium Tubes with Perforated Bottom Made of Titanium-Clad Steel. Advances in Materials Science, 2019, Vol. 19(3), 55-64.

https://doi.org/10.2478/adms-2019-0017

(C) 2020 by the authors. Submitted for possible open access publication under the terms and conditions of the Creative Commons Attribution (CC BY) license (http://creativecommons.org/licenses/by/4.0/). 